\title{
Silica segregation in the Ni/YSZ electrode
}

Hauch, Anne; Jensen, Søren Højgaard; Bilde-Sørensen, Jørgen; Mogensen, Mogens Bjerg

Published in:

Journal of The Electrochemical Society

Link to article, DOI:

10.1149/1.2733861

Publication date:

2007

Document Version

Publisher's PDF, also known as Version of record

Link back to DTU Orbit

Citation (APA):

Hauch, A., Jensen, S. H., Bilde-Sørensen, J., \& Mogensen, M. B. (2007). Silica segregation in the Ni/YSZ electrode. Journal of The Electrochemical Society, 154(7), A619-A626. https://doi.org/10.1149/1.2733861

\section{General rights}

Copyright and moral rights for the publications made accessible in the public portal are retained by the authors and/or other copyright owners and it is a condition of accessing publications that users recognise and abide by the legal requirements associated with these rights.

- Users may download and print one copy of any publication from the public portal for the purpose of private study or research.

- You may not further distribute the material or use it for any profit-making activity or commercial gain

- You may freely distribute the URL identifying the publication in the public portal

If you believe that this document breaches copyright please contact us providing details, and we will remove access to the work immediately and investigate your claim. 
${ }^{a}$ Department of Fuel Cells and Solid State Chemistry and ${ }^{c}$ Department of Materials Research,

Ris $\phi$ National Laboratory, Technical University of Denmark, DK-4000 Roskilde, Denmark

${ }^{b}$ Department of Chemistry, Technical University of Denmark, DK-2800, Lyngby, Denmark

Solid oxide fuel cells were tested as solid oxide electrolysis cells used for high-temperature steam electrolysis. The cells were tested at a variety of operation temperatures, current densities, and gas flows to the electrodes. The cell voltages monitored during the electrolysis operation increased significantly during the first few days of testing. Impedance spectroscopy obtained during electrolysis shows that it is the Ni/yttria-stabilized zirconia (YSZ) electrode that passivates. Reference cells and tested cells were examined in a scanning electron microscope after testing. These postmortem analyses reveal the reason for the observed passivation, because results from energy-dispersive spectroscopy clearly show evidence that silica-containing impurities have segregated to the hydrogen electrode/electrolyte interface during electrolysis testing. Examples of different microstructures and amounts of Si-containing impurities in the electrolyte/hydrogen electrode interface are presented and related to the electrolysis test conditions and the passivation histories of the electrolysis cells.

(C) 2007 The Electrochemical Society. [DOI: 10.1149/1.2733861] All rights reserved.

Manuscript submitted October 24, 2006; revised manuscript received February 27, 2007. Available electronically May 4, 2007.

Solid oxide electrolysis cell (SOEC) for high-temperature steam electrolysis has gained renewed interest during the last few years. ${ }^{1-7}$ This is due to the present high oil prices, ${ }^{8,9}$ increasing interest in renewable energy technologies, ${ }^{10-12}$ and the improvements in performance obtained via the solid oxide fuel cell (SOFC) research and development. ${ }^{13-16}$

Besides steam electrolysis, the SOEC is capable of $\mathrm{CO}_{2}$ electrolysis. ${ }^{17-19}$ The high temperature and good kinetics provide a possibility for a very efficient synthesis gas production at economically optimized operating conditions. ${ }^{19}$ The syn-gas can be catalyzed into various types of synthetic fuels. ${ }^{20}$

For such SOECs to become interesting from a commercial point of view, the cells need to be long-term stable with a minimum internal resistance of the cell in order to keep the investment cost and the hydrogen production price low. Small differences in the level of impurities in the raw materials have been shown to have a large effect on the durability and the degree of passivation for model systems of the SOFC anodes. ${ }^{21,22}$ This work reports on microscopy investigations of impurities in the hydrogen electrode/electrolyte interface of solid oxide cells (SOCs) after electrolysis operation. It is shown that substantial amounts of impurities can be found in the few micrometers of the hydrogen electrode closest to the electrolyte and that the amount and microstructure of these impurities vary depending on the operation conditions during electrolysis.

\section{Experimental}

Electrolysis tests and test setup.- Ni/yttria-stabilized zirconia (YSZ)-supported SOFCs produced at Risø National Laboratory were used as SOECs for high-temperature steam electrolysis. Detailed information about the composition of the electrodes and the dimension of the tested cells as well as detailed information about the cell test setup is given elsewhere. ${ }^{23-25}$ The cells were operated at different temperatures, current densities, and gas flows to the electrodes during the electrolysis tests. The values for partial pressure of gases given here are values at the steam inlet. The cell voltage was monitored as a function of time. Reference cells were obtained by applying the usual heating up and $\mathrm{NiO}$-reduction procedure to cells from the same production batch as the cells used for electrolysis testing. After obtaining a cell voltage close to the one expected from the calculated Nernst potential, the cooling down of the reference cells was started. A Solartron 1260 in combination with a shunt was used for impedance spectroscopy (IS) during the electrolysis. The setup is described by Bonanos. ${ }^{26}$

\footnotetext{
* Electrochemical Society Active Member.

${ }^{\mathrm{z}}$ E-mail: anne.hauch@risoe.dk
}

Raw materials and sample preparation.- TZ8Y

$\left(\mathrm{ZrO}_{2}\right.$, $8 \mathrm{~mol} \% \mathrm{Y}_{2} \mathrm{O}_{3}$, Tosoh) was used for the electrolyte and the $10 \mu \mathrm{m}$ thick active hydrogen electrode. For the $300 \mu \mathrm{m}$ thick Ni/YSZ support layer TZ3Y $\left(\mathrm{ZrO}_{2}, 3 \mathrm{~mol} \% \mathrm{Y}_{2} \mathrm{O}_{3}\right.$, Tosoh) was used. For both the active electrode and the support layer the $\mathrm{NiO}$ for the $\mathrm{Ni} / \mathrm{YSZ}$ cermet was supplied by Alfa Aesar, Johnson Matthey Company. The chemical composition of the raw materials according to the specifications from the suppliers together with impurity analysis by glow discharge mass spectroscopy (GDMS) is given in Table I. The organic solutions used for the YSZ slurry for the production of the cells also contain impurities, but the amount of silicon originating from the organic compounds used in the cell production is only approximately $1 / 10$ of the amount of silicon from the YSZ.

The cells were prepared for scanning electron microscopy (SEM) investigation by vacuum embedding pieces of the cells in epoxy (EpoFix from Struers) followed by grinding and polishing. The samples were subsequently coated with carbon. It has been shown that the presence of epoxy as mounting material does not interfere with the impurity analysis. ${ }^{21}$

SEM and energy-dispersive spectroscopy. - Reference cells and the tested cells were examined in a Zeiss Supra 35 field emission scanning electron microscope (FESEM) equipped with the Noran System SIX X-ray microanalysis system. Two tested cells and two reference cells were investigated. The energy-dispersive spectroscopy (EDS) was obtained at an acceleration voltage of $10-12 \mathrm{kV}$. Monte Carlo simulations show that at an acceleration voltage of $10 \mathrm{kV}$, the detected X-rays originate from a maximum depth in the material from $\sim 400 \mathrm{~nm}$ for $\mathrm{Ni}(\mathrm{L} \alpha)$ to $\sim 750 \mathrm{~nm}$ for $\mathrm{Zr}(\mathrm{L} \alpha)$, and a spatial resolution of approximately $1 \mu \mathrm{m}$ can be expected for the elements of interest. A counting time of $60 \mathrm{~s}$ was used for the point EDS. For the line scan the distance between each individual EDS was $0.06 \mu \mathrm{m}$ and the counting time was $30 \mathrm{~s}$ for each point. EDS maps were recorded over $30 \mathrm{~min}$ with a resolution of $256 \times 192$ pixels, corresponding to 10 pixels per micrometer at the selected magnification.

Quantification was made by standard less analysis. Element concentrations were calculated using the $\mathrm{K} \alpha$ line for $\mathrm{O}, \mathrm{C}, \mathrm{Al}$, and $\mathrm{Si}$. The L $\alpha$ line was used for Ni, Y, and Zr. Peak overlap only occurred for $\mathrm{Y}$ and $\mathrm{Zr}$. The detection limit for silicon and sodium is estimated to be $0.1 \mathrm{wt} \%$. The relative uncertainty for the EDS analysis is generally $\pm 5 \%$, though it could be up to $\pm 10 \%$ for analysis of elements which are only present at very low concentrations. 


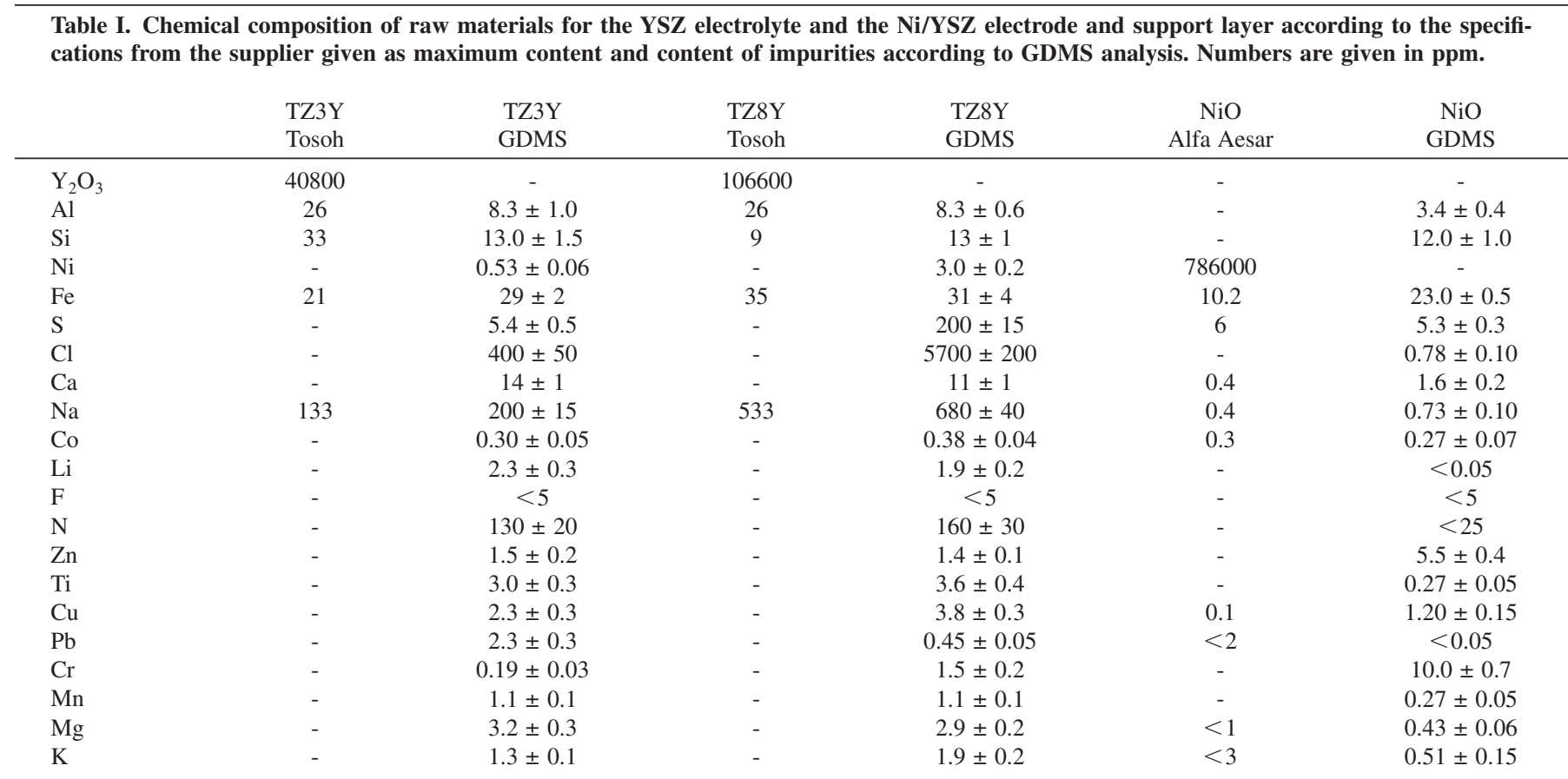

Table II. Operation conditions for cell test A. Numbers in first column correspond to the numbers in Fig. 1.

\begin{tabular}{|c|c|c|c|c|c|c|}
\hline No. & Time (h) & $\begin{array}{c}\text { Gas to } \mathrm{H}_{2} \text { electrode } \\
(\mathrm{L} / \mathrm{h})\end{array}$ & $\begin{array}{l}\text { Gas to } \mathrm{O}_{2} \\
\text { electrode }\end{array}$ & $\begin{array}{l}\text { Current } \\
\text { density } \\
\left(\mathrm{A} / \mathrm{cm}^{2}\right)\end{array}$ & $\begin{array}{l}\text { Nernst } \\
\text { potential } \\
(\mathrm{mV})\end{array}$ & $\begin{array}{c}\text { Temperature } \\
\left({ }^{\circ} \mathrm{C}\right)\end{array}$ \\
\hline 1 & $34-40$ & $1.0 / 18.0 \mathrm{H}_{2} \mathrm{O} / \mathrm{H}_{2}$ & Air & 0 & 1025 & 850 \\
\hline 2 & $115-166$ & $1.2 / 24.0 \mathrm{H}_{2} \mathrm{O} / \mathrm{H}_{2}$ & $\mathrm{O}_{2}$ & 0 & 1107 & 850 \\
\hline 3 & $166-168$ & $12.5 / 1.6 \mathrm{H}_{2} \mathrm{O} / \mathrm{H}_{2}$ & $\mathrm{O}_{2}$ & 0 & 824 & 950 \\
\hline 4 & $168-329$ & $12.5 / 1.6 \mathrm{H}_{2} \mathrm{O} / \mathrm{H}_{2}$ & $\mathrm{O}_{2}$ & -0.5 & 863 & 850 \\
\hline 5 & $368-388$ & $1.3 / 24.0 \mathrm{H}_{2} \mathrm{O} / \mathrm{H}_{2}$ & $\mathrm{O}_{2}$ & 0 & 1104 & 850 \\
\hline 6 & $388-406$ & $2.3 / 10.0 \mathrm{CO}_{2} / \mathrm{CO}$ & $\mathrm{O}_{2}$ & 0 & 990 & 950 \\
\hline 7 & $406-424$ & $30.2 / 10.0 \mathrm{CO}_{2} / \mathrm{CO}$ & $\mathrm{O}_{2}$ & -1.0 & 854 & 950 \\
\hline 8 & $424-497$ & $12.6 / 12.6 \mathrm{H}_{2} \mathrm{O} / \mathrm{H}_{2}$ & $\mathrm{O}_{2}$ & 1.0 & 932 & 950 \\
\hline 9 & $497-498$ & $5.0 / 20.0 \mathrm{H}_{2} \mathrm{O} / \mathrm{H}_{2}$ & $\mathrm{O}_{2}$ & 0 & 990 & 950 \\
\hline 10 & $498-525$ & $12.6 / 12.6 \mathrm{H}_{2} \mathrm{O} / \mathrm{H}_{2}$ & $\mathrm{O}_{2}$ & 1.0 & 932 & 950 \\
\hline 11 & $525-1000$ & $4.5 / 2.3 \mathrm{H}_{2} \mathrm{O} / \mathrm{H}_{2}$ & $\mathrm{O}_{2}$ & -1.0 & 897 & 950 \\
\hline
\end{tabular}

\section{Results}

Test A: electrolysis testing.- A history plot for the cell voltage during the entire test A is shown in Fig. 1, and the different operation conditions during testing are given in Table II. The two main electrolysis test periods are marked by the numbers 4 and 11 in Fig. 1 , and the electrolysis conditions were $-0.5 \mathrm{~A} / \mathrm{cm}^{2}$ at $850^{\circ} \mathrm{C}$, applying $90 \%$ steam and $10 \%$ hydrogen in the inlet gas to the $\mathrm{Ni} / \mathrm{YSZ}$ electrode, and later $-1.0 \mathrm{~A} / \mathrm{cm}^{2}$ at $950{ }^{\circ} \mathrm{C}$, applying $66 \%$ steam and $34 \%$ hydrogen in the inlet gas to the $\mathrm{Ni} / \mathrm{YSZ}$ electrode. As observed previously for other test conditions, ${ }^{25,27}$ the cell passivates ${ }^{\mathrm{d}}$ within the first few days. The cell voltage increased $49 \mathrm{mV}$ over $161 \mathrm{~h}$ during the first $\mathrm{H}_{2} \mathrm{O}$ electrolysis test period and $221 \mathrm{mV}$ over $474 \mathrm{~h}$

\footnotetext{
d The term "passivation" is used in this work to describe reversible loss in performance for the cell, whereas "degradation" describes an irreversible loss of performance.
}

during the last $\mathrm{H}_{2} \mathrm{O}$ electrolysis test period. The short period of $\mathrm{CO}_{2}$ electrolysis (marked 7 in Fig. 1) led to an increase in the cell voltage of $29 \mathrm{mV}$.

Test A: SEM/EDS results. - It has not been possible to find delamination between the electrolyte and the electrodes, cracks in the electrolyte, or similar types of changes in the tested cell A. The upper part of Fig. 2 shows a SEM image of the electrolyte/hydrogen electrode interface for test A after electrolysis testing. Point EDS were recorded at the three colored points marked in the SEM image. The lower part of Fig. 2 shows the EDS obtained at the three points. The color of the lines in the spectra specifies where each EDS was obtained on the sample. It is seen that Si and YSZ are present as oxides. On the contrary $\mathrm{Ni}$ is not oxidized. The calculated atom percentages and weight percentages of the oxides obtained for the three spectra in Fig. 2 are given in Table III. The main constituents for the "red spectrum" are $\mathrm{Si}$ and $\mathrm{O}$, and only few atom percentages of $\mathrm{Ni}, \mathrm{Y}, \mathrm{Z}, \mathrm{Al}$, and $\mathrm{Na}$ were detected. The $\mathrm{Si} / \mathrm{O}$ ratio was close to 0.5 , and silicon most likely exists as $\mathrm{SiO}_{2}$ in this grain of impurity. 


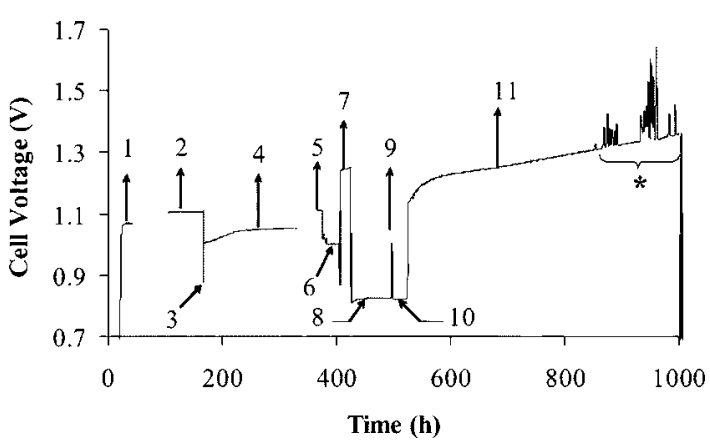

Figure 1. Cell voltage vs time for test A. The numbers next to the cell voltage curve correspond to the numbers in the first column in Table III in which the operating conditions are given. Characterization (I-V curves, IS, and gas shift experiments) of the cell was performed from 41-105 h and 329-360 h of testing. * denotes that the observed instability was caused by temperature control problems.

Note that only the $\mathrm{Si}$ and $\mathrm{O}$ peak seems to be present in the point EDS recorded at the red mark, besides carbon from the mounting material. This reveals that even though it can be difficult to see the borders of the silica particle in the SEM image, the $\mathrm{SiO}_{2}$ particle actually occupies the main part of the sampling volume and therefore has a diameter of approximately $1 \mu \mathrm{m}$. The presence of sodium in the red point (Table III) can be difficult to see in the spectrum
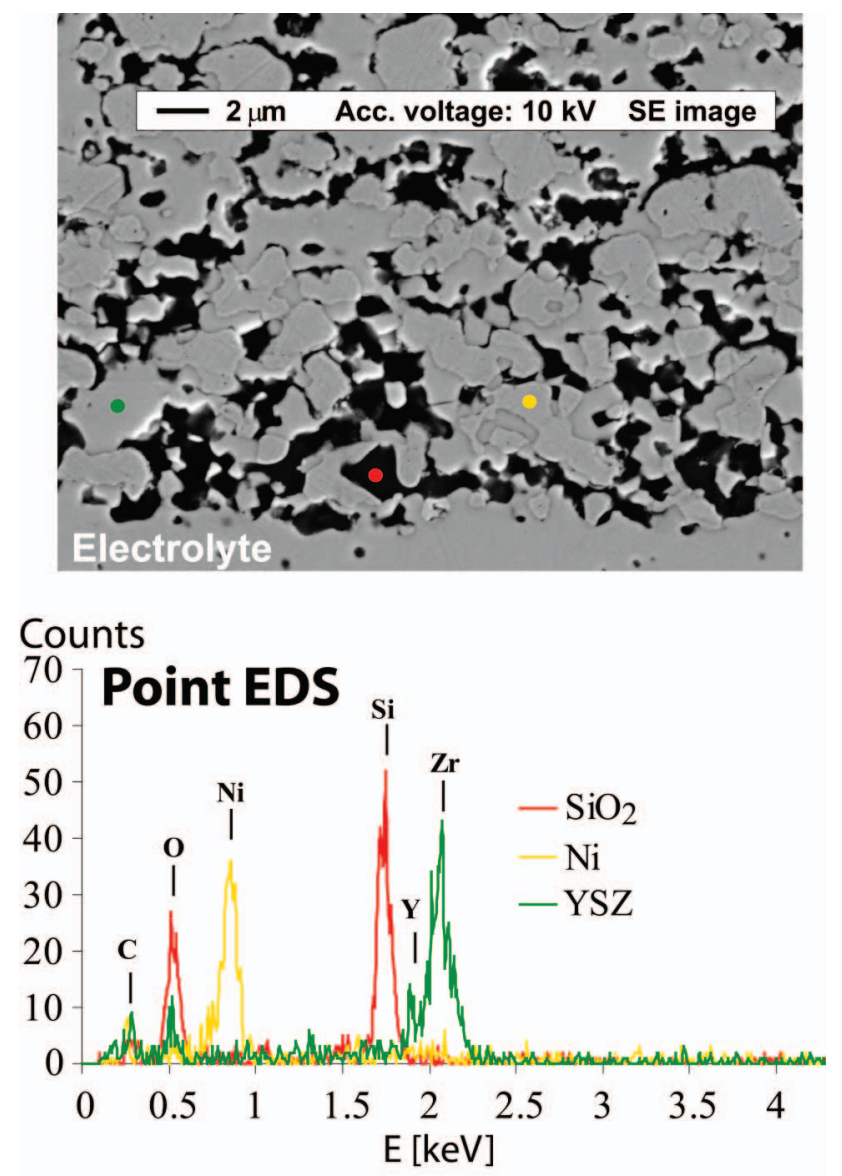

Figure 2. (Color online) Postmortem SEM secondary electron (SE) image of test A. Three colored points are shown on the SE image. EDS for each point is shown in the same color below the SEM image.

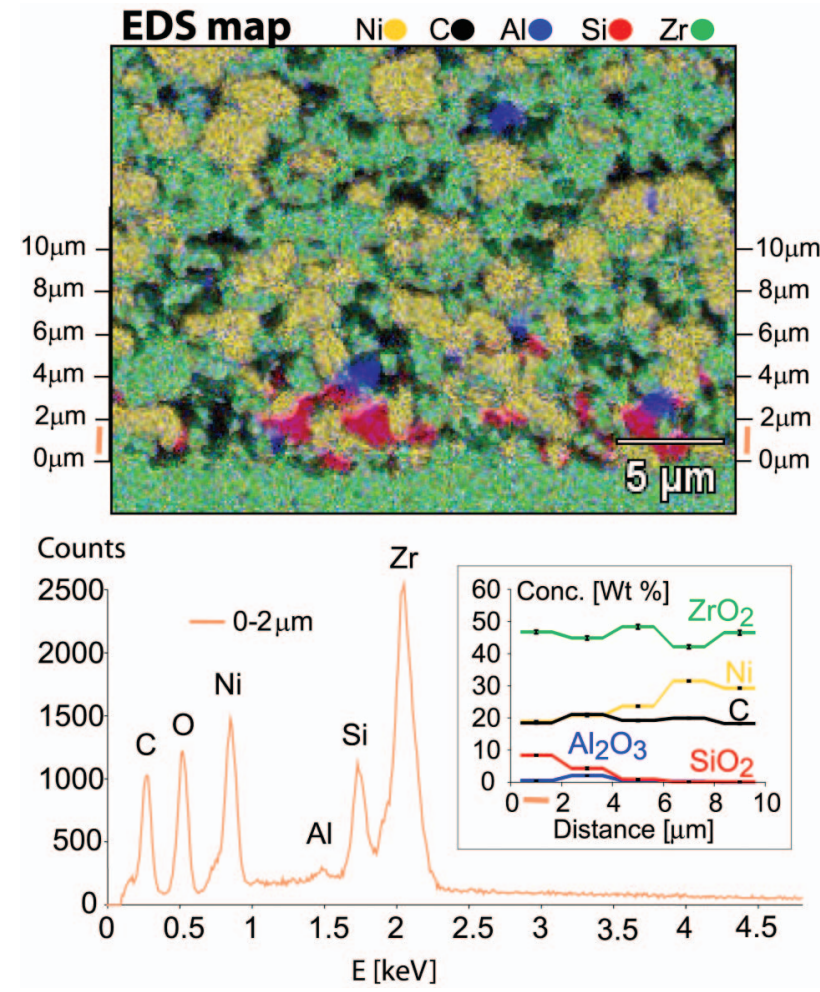

Figure 3. (Color online) EDS mapping of $\mathrm{Si}$ (red), $\mathrm{Al}$ (blue), $\mathrm{Zr}$ (green), $\mathrm{Ni}$ (yellow), and C (black). The carbon comes from holes in the porous electrode filled with epoxy. The EDS shown below are additive spectra of all point EDS lying within a specified distance from the electrode/electrolyte interface. Concentrations of compounds are calculated based on the additive EDS. The concentration for each compound is given as a function of interval distance from the electrolyte in the inset.

given in Fig. 2 because of the low counting time. ${ }^{\mathrm{e}}$ Point EDS with a counting time of $60 \mathrm{~s}$ also shows the presence of $\mathrm{Na}$ in the $\mathrm{Si}$ containing grains of impurities. The $\mathrm{Na} / \mathrm{Si}$ ratio is typically between 1:14 and 1:34 in the Si-containing impurities. Both sodium and silicon are most likely present as oxides.

An element map of the cell area in Fig. 2 is shown in Fig. 3. The rather large particles of alumina observed in Fig. 3 can originate from alumina that is added as a sintering aid during the cell manufacturing and such alumina particles are also found in the reference cells. Area analysis using EDS data originating from the area between 0 and $2 \mu \mathrm{m}$ from the electrolyte was obtained and the resulting spectrum is shown below the element map in Fig. 3. The corresponding counting time for the spectrum in Fig. 3 was $180 \mathrm{~s}$ for the area of $2 \times 30 \mu \mathrm{m}$. Compound weight percents were calculated based on the spectra from the EDS originating from the $0-2,2-4$, $4-6,6-8$, and $8-10 \mu \mathrm{m}$ regions from the electrolyte. ${ }^{\mathrm{f}}$ The inset in Fig. 3 shows the calculated concentrations as a function of distance from the electrolyte. Note how the $\mathrm{SiO}_{2}$ concentration decreases with increasing distance from the electrolyte. Several mappings similar to the one shown in Fig. 3 have been made for this cell and Si could not be detected in the spectra obtained at a distance more than $8 \mu \mathrm{m}$ from the electrolyte for any of them. Furthermore, the silica content in the innermost $2 \mu \mathrm{m}$ close to the electrolyte varied

\footnotetext{
The spectra for the points shown in the upper part of Fig. 2 are extracted from the mapping $(30 \mathrm{~min})$ of the entire image using the "Spectral Imaging" feature in Noran System SIX. Therefor, the EDS for these points correspond to a counting time of only approximately $5 \mathrm{~s}$.

Area spectra from an inhomogeneous area do not strictly fulfill the conditions for $\mathrm{ZAF}$ corrections. The absolute value of the $\mathrm{Si}$ content is therefore somewhat uncertain, but the curve in Fig. 3 is expected to reflect the relative variation correctly.
} 

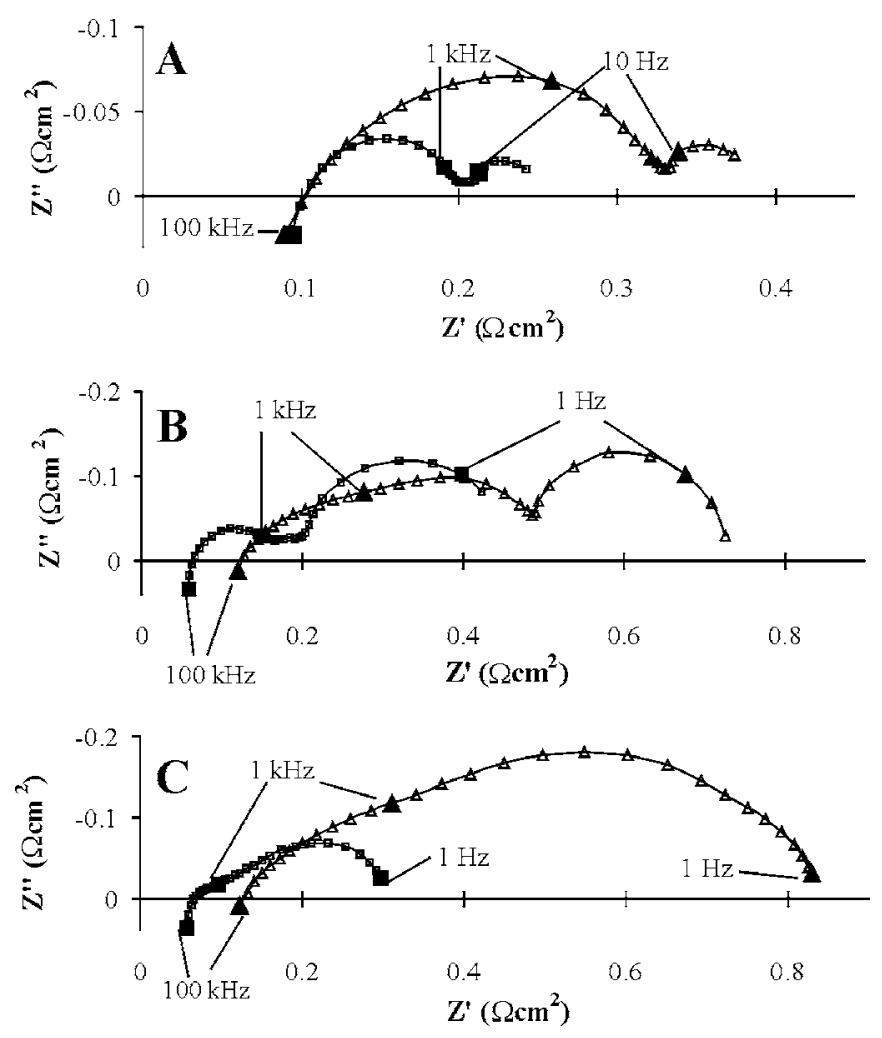

Figure 4. Impedance spectra recorded during test A. IS marked by triangles are the last recorded IS in each figure. Part A: During the first electrolysis test period at $t=166 \mathrm{~h}$ and $t=329 \mathrm{~h}$. Part B: During the last electrolysis test period at $t=526 \mathrm{~h}$ and $t=999 \mathrm{~h}$. Part C: At $\mathrm{OCV}\left(950{ }^{\circ} \mathrm{C}, 5 \% \mathrm{H}_{2} \mathrm{O}\right.$, and $95 \% \mathrm{H}_{2}$ to the Ni/YSZ electrode) before the first electrolysis test at $t$ $=93 \mathrm{~h}$ and after the last electrolysis test at $t=1001 \mathrm{~h}$. See Table II for operation conditions for spectra recorded during electrolysis testing.

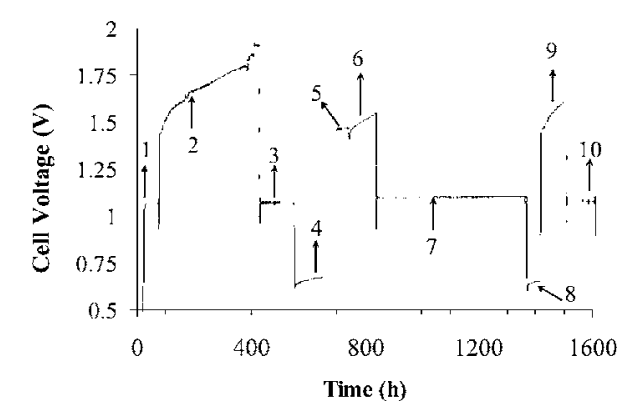

Figure 5. Cell voltage vs time for test $B$. The numbers next to the cell voltage curve correspond to the numbers in the first column in Table IV in which the operating conditions are given. Characterization ( $I-V$ curves, IS, and gas shift experiments) of the cell was performed from 32-76, 504-560, and $670-713 \mathrm{~h}$ of testing.

along the electrode/electrolyte interface from no detectable silica to a maximum of $\sim 8 \mathrm{wt} \% \mathrm{SiO}_{2}$, which is the interface region shown in Fig. 3. The variation in $\mathrm{SiO}_{2}$ content was examined along an electrode/electrolyte interface of $0.8 \mathrm{~cm}$.

Test A: IS during testing. - Part A of Fig. 4 shows an IS obtained just after the beginning of the first electrolysis test period for test A and an IS obtained just before ending the first electrolysis test period (see Table II). Note that the real part of the impedance $\left(Z^{\prime}\right)$ at $100 \mathrm{kHz}$ is constant during this first electrolysis test period. This corresponds to a constant ohmic resistance while the polarization resistance increases. The IS shown in part B of Fig. 4 was recorded just after starting and just before ending the last electrolysis test period for test A. Here it is observed that both the polarization and ohmic resistance increase. Part C of Fig. 4 shows two IS recorded at open-circuit voltage $(\mathrm{OCV})$, one recorded before the first electrolysis testing at $t=93 \mathrm{~h}$ and after ending the last electrolysis test period at $t=1001 \mathrm{~h}$.

Test B: electrolysis testing.- A history plot for the cell voltage during the entire test B is shown in Fig. 5, and the different operation conditions during testing are given in Table IV. The main elec-

\begin{tabular}{|c|c|c|c|c|c|c|c|c|}
\hline & $\mathrm{Si}$ & $\mathrm{Ni}$ & $\mathrm{Zr}$ & $\mathrm{Y}$ & $\mathrm{Al}$ & $\mathrm{Na}$ & $\mathrm{O}$ & $\mathrm{C}$ \\
\hline Red & $26(81)$ & $0.5(1.5)$ & $0.5(3.1)$ & - & 0.7 (1.9) & $1.5(2.5)$ & 54 & 17 \\
\hline Yellow & - & $55 \quad(83)$ & $1.1(3.4)$ & $0.5(1.5)$ & - & & 3 & 40 \\
\hline Green & - & - & $20 \quad(77)$ & $5.0 \quad(17)$ & - & & 48 & 27 \\
\hline
\end{tabular}

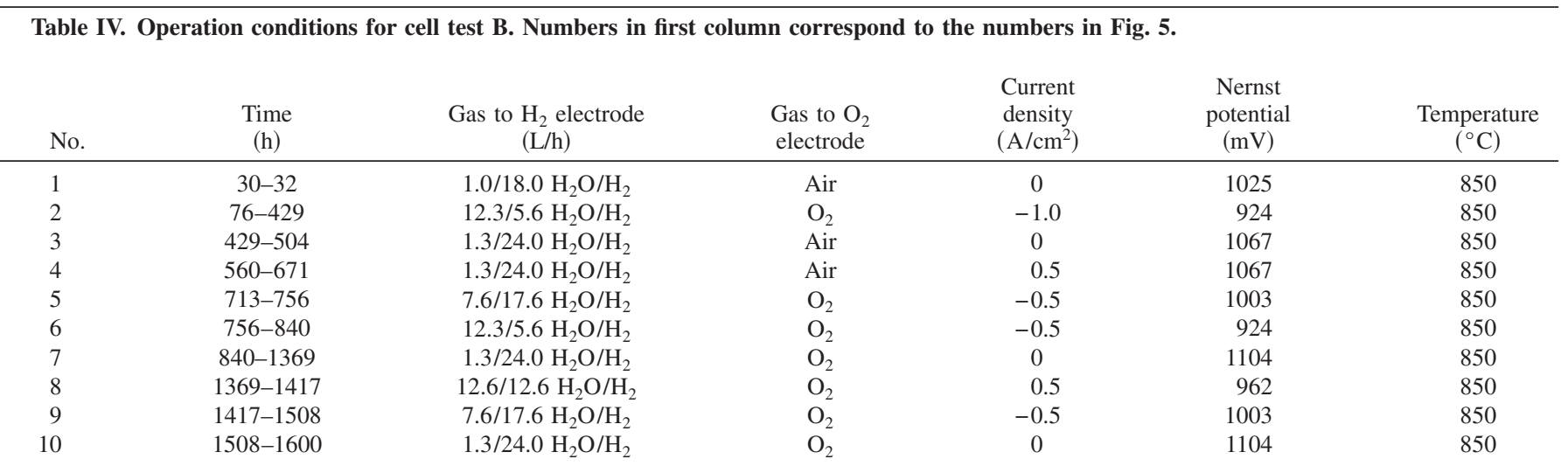




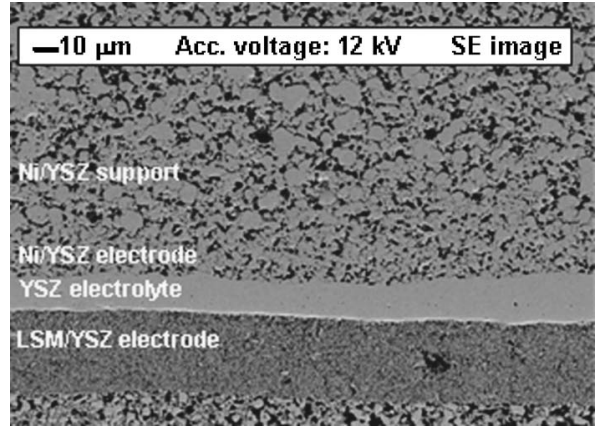

Figure 6. Low-magnification SEM image of the cell used for test B. No cracks in the electrolyte or delamination between electrolyte and the electrodes could be found.

trolysis test period is marked by the number 2 in Fig. 5, and the electrolysis conditions were $-1.0 \mathrm{~A} / \mathrm{cm}^{2}$ at $850{ }^{\circ} \mathrm{C}$, applying $70 \%$ steam and $30 \%$ hydrogen in the inlet gas to the Ni/YSZ electrode. During the main electrolysis test period, the cell voltage increased $479 \mathrm{mV}$ over $351 \mathrm{~h}$. Later, during testing of cell B, three shorter electrolysis test periods were run at a current density of $-0.5 \mathrm{~A} / \mathrm{cm}^{2}$ (marked 5, 6, and 9 in Fig. 5). Test B was also operated in fuel cell mode at $0.5 \mathrm{~A} / \mathrm{cm}^{2}$ at $850{ }^{\circ} \mathrm{C}$ with $5 \%$ steam and $95 \%$ hydrogen in the inlet gas to the Ni/YSZ electrode (marked 4 and 8 in Fig. 5).
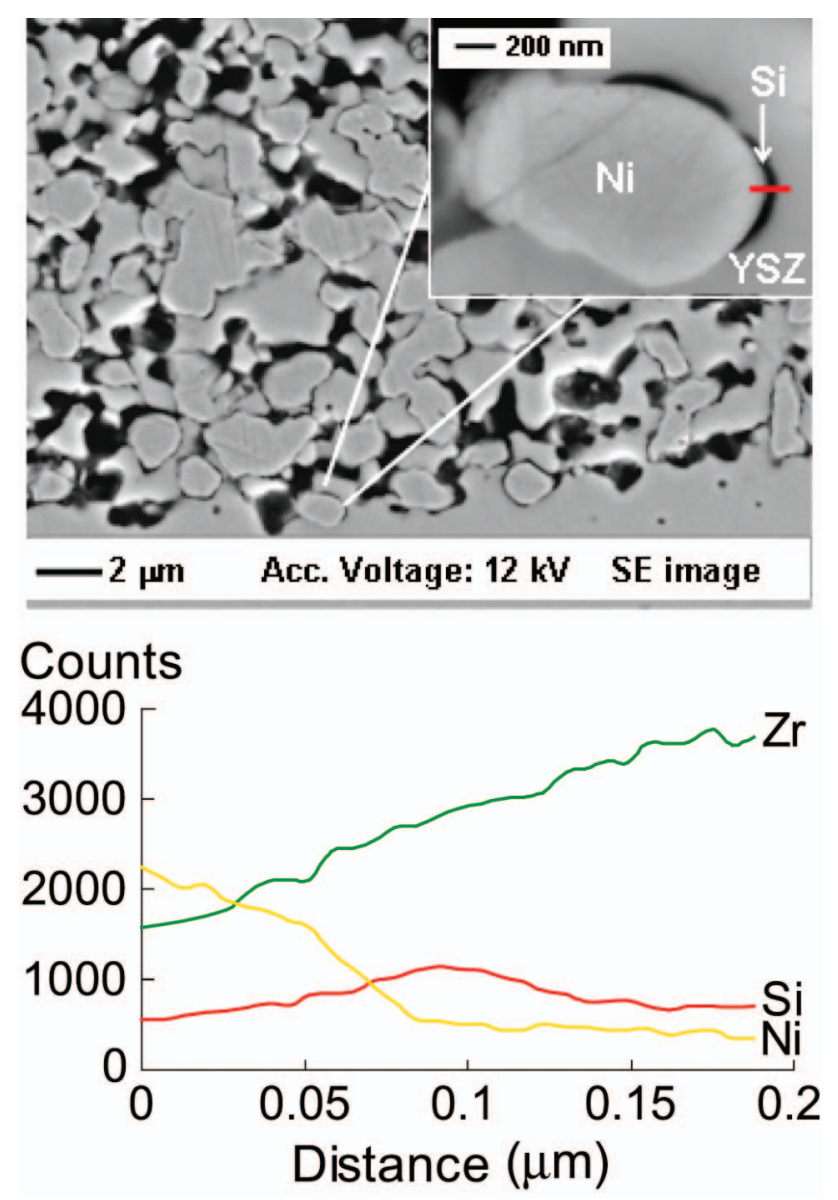

Figure 7. (Color online) The upper part is a SEM image of test B. Note the black "lines" between the Ni and YSZ particles. The inset is a zoom on a Ni particle adjacent to the electrolyte. The red line in the inset shows where the EDS line scan was made.
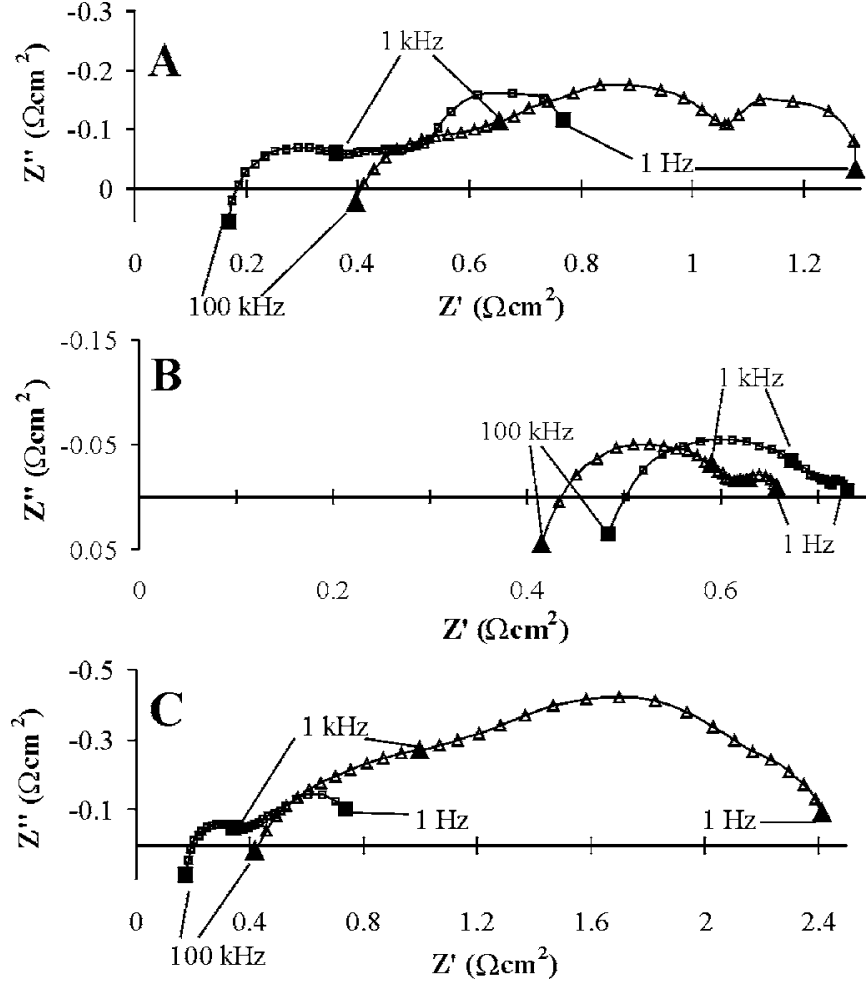

Figure 8. Impedance spectra recorded during test B. IS marked by triangles are the last recorded IS in each figure. Part A: During the first electrolysis test at $t=77 \mathrm{~h}$ and $t=380 \mathrm{~h}$. Part B: During the first fuel cell test period at $t=561 \mathrm{~h}$ and $t=679 \mathrm{~h}$. Part C: At OCV $\left(850^{\circ} \mathrm{C}, 5 \% \mathrm{H}_{2} \mathrm{O}\right.$, and $95 \% \mathrm{H}_{2}$ to the Ni/YSZ electrode) before the first electrolysis test period at $t=49 \mathrm{~h}$ and after the last electrolysis test period at $t=1514 \mathrm{~h}$. See Table IV for operation conditions for spectra recorded during electrolysis testing.

Test B: SEM/EDS results. - A representative overview SEM image is shown in Fig. 6. Even though a significant increase in the ohmic resistance was measured during testing, it was not possible to find delamination between the electrolyte and the electrodes, cracks in the electrolyte, or similar changes in the cell used for test B that could be expected to lead to an increase in the ohmic resistance. ${ }^{28}$ The upper part of Fig. 7 is a representative SEM image of a hydrogen electrode/electrolyte interface of the cell from test B at a higher magnification. Note the dark rims between the $\mathrm{Ni}$ and the YSZ particles. The inset is a higher magnification image of one of the $\mathrm{Ni}$ particles adjacent to the electrolyte. The dark rim shown here has a width of approximately $50 \mathrm{~nm}$. A line scan was made at the red line in the inset. The lower part of Fig. 7 shows the counts for $\operatorname{Si}(\mathrm{K} \alpha)$, $\mathrm{Ni}(\operatorname{L} \alpha)$, and $\operatorname{Zr}(\operatorname{L} \alpha)$ as a function of position in the line scan. It is seen that the Si counts has a maximum where the dark rim between the $\mathrm{Ni}$ and the YSZ particles is located, whereas the $\mathrm{Zr}$ counts increase and the Ni counts decrease from the start to the end point of the line scan.

Test B: IS during testing.-Part A in Fig. 8 shows an IS obtained just after the beginning of the first electrolysis test period for test B and an IS obtained just before ending the first electrolysis test period (see Table IV). The polarization resistance as well as the real part of the impedance $\left(\mathrm{Z}^{\prime}\right)$ at $100 \mathrm{kHz}$ (ohmic resistance) increases during the testing at $-1 \mathrm{~A} / \mathrm{cm}^{2}$, in contrast to test A where only the polarization resistance increased during the first electrolysis period at $-0.5 \mathrm{~A} / \mathrm{cm}^{2}$. Both the polarization and ohmic resistance increased during the shorter second and third electrolysis test period $(-0.5$ $\mathrm{A} / \mathrm{cm}^{2}$ ) for test B. Part B of Fig. 8 shows two IS recorded during the first fuel cell test period $\left(0.5 \mathrm{~A} / \mathrm{cm}^{2}\right)$ at $t=561 \mathrm{~h}$ and $t=679 \mathrm{~h}$. During this fuel cell test period the real part of the impedance $\left(\mathrm{Z}^{\prime}\right)$ 
at $100 \mathrm{kHz}$ (ohmic resistance) decreases. Part $\mathrm{C}$ of Fig. 8 shows two IS recorded at OCV, one recorded before the first electrolysis testing at $t=49 \mathrm{~h}$ and after ending the third electrolysis test period at $t=$ $1514 \mathrm{~h}$.

\section{Discussion}

The IS results presented by Hauch and Jensen et al. ${ }^{25,27}$ verifies that the observed passivation during electrolysis testing of these cells relates to processes in the Ni/YSZ electrode and the SEM/EDS analyses have therefore been focused on the Ni/YSZ-electrolyte interface. Si was found in the hydrogen electrode after testing for both test $\mathrm{A}$ and $\mathrm{B}$. In test $\mathrm{A}$ it was shown to occur in an oxidized state, as $\mathrm{SiO}_{2}$. A few atomic percents of sodium were detected in many of the $\mathrm{Si}$-containing impurity particles. No $\mathrm{Si}$ was detected in two reference cells. This verifies that the accumulation of impurities at the hydrogen electrode/electrolyte interface is a result of the testing of the cell and not a result of the production method for the cells. Si-containing impurities have been found on half-cells in setups with YSZ electrolyte pellets. ${ }^{21,29}$ In these cases it was believed that the Si-containing impurities segregated from the $\mathrm{Ni}$ electrode and the YSZ electrolyte to the electrode/electrolyte interface. Long-term fuel cell testing of similar cells using the same test setup as for the electrolysis testing has not led to Si segregation to the electrode/ electrolyte interface to an extent that can be observed using EDS. In test $\mathrm{A}$ the Si-containing impurities segregate to the three phase boundary (3PB) at the electrode/electrolyte interface. In test B the distribution of impurities is different from test $\mathrm{A}$, and impurities tend to segregate to the two phase boundary (2PB) between the $\mathrm{Ni}$ and the YSZ. Several other electrolysis tested cells have been examined by SEM and EDS. For some of these cells it has not been possible to detect Si-containing impurities as found in tests A and B. The cells, for which no impurities have been detected by SEM/EDS, were all tested at current densities of $-0.5 \mathrm{~A} / \mathrm{cm}^{2}$ or below, and only the polarization resistance and not the ohmic resistance increased during these electrolysis tests. The fact that no Si was detected by SEM/ EDS for these cells does not necessarily mean that Si-containing impurities are absent at the electrolyte/electrode interface for these cells, but only that the amount of possible $\mathrm{Si}$ impurities is below the detection limit of approximately $0.1 \mathrm{wt} \%$ for $\mathrm{Si}$.

In general, SEM investigation of electrolysis tested cells shows that the microstructures of the Ni/YSZ have changed slightly when compared with a reference cell, but Ni/YSZ microstructures for heavily passivated (large overpotential) and only slightly passivated (small overpotential) electrolysis cells are alike. There is a relation between the degree of passivation during electrolysis testing and the findings of silica-containing impurities in the tested hydrogen electrodes. An example of this is found by comparing the electrolysis test results (overpotential and IS) with the SEM/EDS findings, e.g., for test $\mathrm{B}$ in this work and tests $\mathrm{C}$ and $\mathrm{D}$ reported by Hauch et al. ${ }^{25}$ which were all operated at $850^{\circ} \mathrm{C}$ and $p_{\mathrm{H}_{2} \mathrm{O}}=0.7 \mathrm{~atm}$, but with current densities of $-1,-0.5$, and $0.25 \mathrm{~A} / \mathrm{cm}^{2}$, respectively. Test $\mathrm{B}$ was heavily passivated, test $\mathrm{C}$ was "medium" passivated, and test $\mathrm{D}$ was only slightly passivated. They had similar Ni/YSZ microstructures. As shown here, a large amount of silica-containing impurities was found in the Ni/YSZ electrode of test $\mathrm{B}$, traces (close to the detection limit for EDS) of impurities were found in the $\mathrm{Ni} / \mathrm{YSZ}$ electrode of test $\mathrm{C}$, and no impurities were detected in the Ni/YSZ electrode of test D, i.e., the amount of impurities was below the detection limit for EDS. This combination of electrolysis test results and SEM/EDS investigations for electrolysis cells that have been passivated to different degrees illustrates that if not solely, then at least the main reason for passivation of the cells is the segregation of impurities in the hydrogen electrode of the SOECs.

Composition and properties of impurities. - The chemical composition (Table III) of the Si-containing particles in Fig. 2 is typical of the analysis of impurity particles found close to the electrolyte/ electrode interface for test A. Sodium and aluminum oxides are often found in small amounts in the Si-containing particles. The impurities detected at this interface are most likely a glassy phase This is in good agreement with the transmission electron microscopy (TEM)/EDS analysis results obtained by Liu and Jiao for the Si glass found at the interface of a long-term tested Ni-YSZ (anode)/ YSZ (electrolyte) half-cell. ${ }^{30}$ In contrast to the work by Liu and Jiao, we have not been able to detect calcium oxide in the impurity particles in the electrolyte/electrode interface of test A.

Sodium is known to be a network modifier for silica glasses as it creates nonbridging oxygen atoms and thereby breaks up the silica network structure. At high temperatures the presence of $\mathrm{Na}_{2} \mathrm{O}$ in the silica glass therefore decreases the viscosity of the glass compared with that of pure $\mathrm{SiO}_{2}$ glass. ${ }^{31,32}$ The presence of alumina in a $\mathrm{Si}$ glass phase is known to increase the surface tension and the viscosity. ${ }^{33}$ For this reason alumina has been suggested as a scavenger for $\mathrm{SiO}_{2}$ impurities in YSZ. ${ }^{34}$ To separate the effect of the $\mathrm{Al}_{2} \mathrm{O}_{3}$ found as an impurity in the raw materials and the $\mathrm{Al}_{2} \mathrm{O}_{3}$ added to the support layer as a sintering aid, cells without additional alumina have been produced and will be tested as electrolysis cells. Not only sodium and alumina oxides influence the physical properties of silica glasses, but also the $\mathrm{H}_{2} \mathrm{O}$ content has a large effect on the viscosity of various silica glasses. ${ }^{32,35-37}$ The addition of only $0.12 \%$ $\mathrm{H}_{2} \mathrm{O}$ to a $\mathrm{SiO}_{2}$ glass has been shown to decrease the viscosity of the $\mathrm{SiO}_{2}$ glass three orders of magnitude at $1000^{\circ} \mathrm{C}^{32}$ and Shelby ${ }^{37}$ reported that the viscosity of sodium trisilicate glasses decreases by factor of 9 at $440^{\circ} \mathrm{C}$ upon changing the water content from 110 to $1850 \mathrm{ppm}$. Test A was operated at $850^{\circ} \mathrm{C}$ with a mixture of $0.9 \mathrm{~atm}$ $\mathrm{H}_{2} \mathrm{O}$ and 0.1 atm $\mathrm{H}_{2}$ to the hydrogen electrode throughout the first electrolysis test period, giving "water-rich" conditions for the formation and segregation of Si glass-phase impurities in the hydrogen electrode. For the longer electrolysis test periods the steam content was at least $66 \%$ for both tests. The glassy phase impurities therefore probably had very low viscosity at the electrolysis operation conditions. Liu et al. also reported a correlation between the water concentration profile and damages caused by the glassy phase. ${ }^{21}$

Sources for the detected Si in tested cells.- There are at least two obvious sources for the Si-containing impurities: $(i)$ impurities in the raw materials and (ii) the glass sealing around the cell and gas distributors. ${ }^{25}$ Let us make a rough estimate of the total mass of $\mathrm{Si}$ in the cells coming from the raw materials. Because it has been reported that impurities such as $\mathrm{Si}, \mathrm{Na}$, and $\mathrm{Al}$ from the bulk of YSZ can segregate to the grain boundaries, external surfaces, and interfaces when annealed at $800-1500^{\circ} \mathrm{C},{ }^{38}$ the total amount and not only surfaces of the raw material used for the manufacture of one cell is applied in the calculation. With the cell dimensions and specifications given elsewhere for similar cells, ${ }^{25}$ the total mass of the electrolyte, the active hydrogen electrode, and the support layer (before reduction) is approximately $3.6 \mathrm{~g}$ for one cell. According to the GDMS analysis of the raw materials (Table I), this gives a maximum of $\sim 0.1 \mathrm{mg} \mathrm{SiO}$. As mentioned, the $\mathrm{Si}$ content at the electrolyte/electrode interface varies along the interface. Therefore adding up the $\mathrm{SiO}_{2}$ content shown in Fig. 2, Fig. 3, and Table III hardly gives the correct total amount of impurity particles at the interface for the entire cell. However, if the $\mathrm{SiO}_{2}$ content shown in the area of Fig. 3 is used merely to give an estimate of the amount of $\mathrm{SiO}_{2}$ in the cell used for test $\mathrm{A}$, one finds a $\mathrm{SiO}_{2}$ content of $1.4 \mathrm{mg} \mathrm{SiO} 2$ for the entire cell. The estimated values for the mass of $\mathrm{SiO}_{2}$ from raw materials and from EDS results (Fig. 3) indicates that only a few percentages of the hydrogen electrode can be like the part shown in Fig. 3. SEM work on different pieces of the tested cells does not support this. Therefore it is concluded that impurities in the raw materials are hardly the only source for the detected Si impurities in the tested cells.

The glass sealing surrounding the cell is another possible source for the Si-containing impurities. To clarify whether or not the albite $\left(\mathrm{NaAlSi}_{3} \mathrm{O}_{8}\right)$ glass sealing can be expected to give a significant contribution of $\mathrm{Si}$ species over the cell during testing, thermodynamic calculations were made using the Factsage software. As shown previously, ${ }^{39,40}$ the main contributor to the vapor pressure of 
Si species is $\mathrm{Si}(\mathrm{OH})_{4}$. At relevant conditions $\left(850^{\circ} \mathrm{C}, 0.7\right.$ atm $\mathrm{H}_{2} \mathrm{O}$, and $\left.0.3 \mathrm{~atm} \mathrm{H}_{2}\right)$ the vapor pressure of $\mathrm{Si}(\mathrm{OH})_{4}$ over the albite glass is $\sim 10^{-7} \mathrm{~atm}$. For a $500 \mathrm{~h}$ test a rough estimate for the upper limit for the $\mathrm{Si}$ contribution from the glass sealing is $3 \mathrm{mg} \mathrm{SiO}$ at the chosen operation condition. For this estimate the calculated $p_{\mathrm{SiOH}_{4}}$ was used in combination with Fick's first law, a diffusion length through $1 \mathrm{~mm}$ of stagnant gas next to the glass sealing, ${ }^{41}$ the binary diffusion coefficient for water in water, ${ }^{41,42, \mathrm{~g}}$ and the geometry of the cell test setup. The result of this estimate indicates that the vapor pressure of $\mathrm{Si}(\mathrm{OH})_{4}$ over the glass sealing can be a source for the detected Si-containing impurities in the tested cells. The glass sealing is indeed a possible source for the impurities found in the $\mathrm{Ni} / Y S Z$ electrodes, but the experimental results presented here do not give the proof that the silica impurities do indeed originate from the glass sealing. Further tests for investigating the effect of the glass sealing on the passivation of the cells during electrolysis testing of similar cells are necessary and in progress. Visual inspection of the glass sealing after the tests shows that especially the glass sealing at the steam inlet side of the setup has become more porous as a result of testing.

If the origin of the main silicon source is $\mathrm{Si}(\mathrm{OH})_{4}(\mathrm{~g})$ from the sealing then the equilibrium

$$
\mathrm{Si}(\mathrm{OH})_{4}(\mathrm{~g}) \rightleftarrows \mathrm{SiO}_{2}(\mathrm{l})+2 \mathrm{H}_{2} \mathrm{O}(\mathrm{g})
$$

will be forced toward the formation of a glassy phase silica in the regions of the cell where the most steam is reduced to hydrogen, that is, in the few micrometers of the hydrogen electrode closest to the electrolyte, and this would lead to the highest silica content closest to the electrode/electrolyte interface. This is in agreement with the gradient for silica content found for the cell used for test A, where EDS results shown in Fig. 3 led to $8 \mathrm{wt} \% \mathrm{SiO}_{2}$ in the electrode 0-2 $\mu \mathrm{m}$ from the electrolyte, 4 wt $\% \mathrm{SiO}_{2}$ for the electrode 2-4 $\mu \mathrm{m}$ from the electrolyte, and below the detection limit in a distance more than $4 \mu \mathrm{m}$ from the electrolyte. In test B (period 5, Fig. 5) fuel cell operation of the cell led to a $54 \mathrm{mV}$ increase in the cell voltage, corresponding to an activation of the cell. The ohmic resistance decreased $15 \%$ and the polarization resistance decreased $20 \%$ (part B, Fig. 8) during the $121 \mathrm{~h}$ of fuel cell mode operation. Similar reactivation by fuel cell operation of a cell passivated in electrolysis mode was observed for test A (period 8 and 10, Fig. 1) and has been reported for other similar tests. ${ }^{25,27}$ These reactivation results combined with the lack of silica impurities in the Ni/YSZ electrodes of similar cells tested for hundreds of hours as fuel cells using the same type of test setup. ${ }^{28}$ indicate that the fuel cell reactivation of the passivated electrolysis cell can be related to equilibrium 1 . When the cell is used for oxidizing hydrogen, equilibrium 1 is forced toward the formation of $\mathrm{Si}(\mathrm{OH})_{4}$ and thereby evaporates some of the silica that hampers the reactions at the electrode/ electrolyte interface. Another aspect to consider in relation to the activation of the cell used in test $\mathrm{B}$ is phase changes for the impurities as gases are changed to a drier $\mathrm{H}_{2} \mathrm{O} / \mathrm{H}_{2}$ mixture. Leaving the cell for more than $500 \mathrm{~h}$ at OCV at $p_{\mathrm{H}_{2} \mathrm{O}} / p_{\mathrm{H}_{2}}=0.05 / 0.95($ period 7 , Fig. 5) led to a 15 and $13 \%$ decrease in $R_{\text {ohmic }}$ and $R_{\mathrm{p}}$, respectively.

Passivation history for the tested cells.- The passivation histories for tests $\mathrm{A}$ and $\mathrm{B}$ are more complex than for the simple tests of similar SOCs at constant electrolysis conditions as reported previously. ${ }^{25,27}$ The relative changes in both the ohmic and polarization resistances for the two tests are comparable. The increase in the ohmic resistance was 115 and $139 \%$ for tests A and B, respectively, and polarization resistances increased $195 \%$ for test $A$ and $225 \%$ for test $\mathrm{B}$. This is observed from the impedance spectra recorded at OCV before and after the electrolysis testing of the two cells (part C in Fig. 4 and Fig. 8), but the passivation histories for the two cells

\footnotetext{
${ }^{g}$ The binary diffusion coefficient for $\mathrm{H}_{2} \mathrm{O}$ in $\mathrm{H}_{2} \mathrm{O}$ has been calculated and applied for the estimate of the flux of $\mathrm{Si}(\mathrm{OH})_{4}$ from the glass sealing because the diffusion volume for $\mathrm{Si}(\mathrm{OH})_{4}$ was not available.
}

are very different. As illustrated (Fig. 8), the IS recorded during electrolysis testing shows that for test B already the first electrolysis test period led to significant increases in both the polarization and the ohmic resistance, and even though the second and third electrolysis test periods were performed at a lower current density $\left(-0.5 \mathrm{~A} / \mathrm{cm}^{2}\right)$, both the polarization resistance and the ohmic resistance kept increasing. The passivation history of test $\mathrm{A}$ is the reverse of that of test B. Here the first electrolysis test period is at a low current density $\left(-0.5 \mathrm{~A} / \mathrm{cm}^{2}\right)$, and only the polarization resistance increases during this part of the test (Fig. 4). During the last $\mathrm{H}_{2} \mathrm{O}$ electrolysis test at harder conditions $\left(-1 \mathrm{~A} / \mathrm{cm}^{2}\right)$, significant increases in both the polarization and ohmic resistance is observed. The cell voltage increase during the short $\mathrm{CO}_{2}$ electrolysis test period for test $\mathrm{A}$ is approximately a factor of 10 lower than the total increase in cell voltage during the $\mathrm{H}_{2} \mathrm{O}$ electrolysis test periods. The $\mathrm{CO}_{2}$ electrolysis therefore hardly plays a key role in the overall passivation of the cell used for test A. The results from test A cannot preclude the possibility of impurity segregation during $\mathrm{CO}_{2}$ electrolysis, but the impurity segregation in the Ni/YSZ electrode do for sure occur during $\mathrm{H}_{2} \mathrm{O}$ electrolysis, as seen from test $\mathrm{B}$ that was only operated in a $\mathrm{H}_{2} \mathrm{O} / \mathrm{H}_{2}$ atmosphere. We believe these very different passivation histories for the two cells have led to the large differences in the microstructure of the impurities for the two cells. Even though there are large differences in the distribution, microstructure, and amount of impurities found in the two cells, there are some common trends for both cells: $(i)$ impurities are only found in the hydrogen electrode, (ii) the main constituent in the impurities is silica, and (iii) the concentration of impurities is largest closest to the electrode/electrolyte interface and no impurities have been detected more than $\sim 8 \mu \mathrm{m}$ from the electrolyte.

In both tests the polarization resistance increased with time during electrolysis. This might be related to the segregation of Sicontaining impurities to the $3 \mathrm{~PB}$ at the electrode/electrolyte interface. Even though a significant increase (especially compared with fuel cell testing of similar cells ${ }^{28}$ ) in the ohmic resistance was observed, it was not possible to detect delaminations between the electrolyte and the electrode or damages of the electrolyte. The contributions to the ohmic resistance $\left(R_{\text {ohmic }}\right)$ can be written as

$$
R_{\text {ohmic }}=R_{\text {ion,conduc. }}+R_{\mathrm{e}-\text {,conduc. }}+R_{\text {current constriction }}
$$

The ionic and electronic conductivities for the materials used in these cells are well known, and at these operation temperatures the ion conductivity in the YSZ is $\sim 0.1 \mathrm{~S} / \mathrm{cm}$, which is approximately 3 orders of magnitude smaller than the electron conductivity of the electrode materials. ${ }^{43} R_{\text {current constriction includes contributions from }}$ the resistance in the auxiliary layers of the cell test setup, i.e., gas distribution layers and current collector foils. It has been shown that the contributions from the auxiliary layers can be made insignificantly small using this test setup, ${ }^{44}$ and using this test setup it is possible to keep $R_{\text {ohmic }}$ constant for $1500 \mathrm{~h}$ of fuel cell testing at $850^{\circ} \mathrm{C} .^{28}$ We therefore believe that the observed increase in the ohmic resistance is strongly related to the segregation of $\mathrm{Si}$ containing impurities to the Ni-YSZ interface, and this lead to current constrictions for the current passage from the electrolyte to $\mathrm{Ni} / \mathrm{YSZ}$ cermet electrode. Impurity containing rims between the $\mathrm{Ni}$ and YSZ with a shape similar to the ones in the cell from test B (Fig. 7) was found by Liu and Jiao in a tested SOFC half-cell. ${ }^{30}$ The rims were reported to consist of a sodium silicate glass phase, but they were thinner $(10 \mathrm{~nm})$ than those reported here $(40-70 \mathrm{~nm})$. The exact chemical composition and crystal structures of the impurity rims observed in the cell from test B will in future work be analyzed by TEM of a thin lamella cut using a focused ion beam.

The SEM and EDS results presented here provides the basis for the schematic presentation of the hydrogen electrode/electrolyte interfaces shown in Fig. 9. The impurities in the sketch explain the reason for the observed electrode passivation and show the qualitative difference between the two tests. The $\mathrm{Si}$ segregation to the $2 \mathrm{~PB}$ was only observed in test B (Fig. 7) and is probably caused by the 


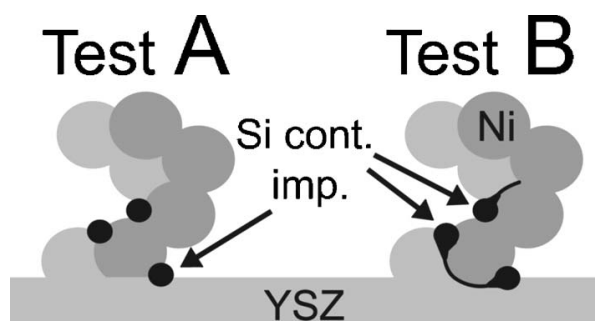

Figure 9. Schematic presentation of Si-containing impurities segregating to the hydrogen electrode/electrolyte interface during electrolysis as observed by SEM. In test $\mathrm{A}$ the impurities tend to block the $3 \mathrm{~PB}$. In test $\mathrm{B}$ the impurities also segregate to the $2 \mathrm{~PB}$ between the $\mathrm{Ni}$ and the YSZ. IS results indicate that also the $2 \mathrm{~PB}$ of test A could contain impurities, but such impurities at the $2 \mathrm{~PB}$ were not observed by SEM for test $\mathrm{A}$.

higher cell voltage (over potential) compared to test A. The increase in the ohmic resistance for test A (Fig. 4) might be caused by impurities that also cover the $2 \mathrm{~PB}$, because silica impurities have been shown to be present in significant amounts in the active layer of the $\mathrm{Ni} / \mathrm{YSZ}$ electrode. The fact that impurities were not found in the 2PB by SEM/EDS investigation of test A only means that they are below the detection limit.

\section{Conclusion}

SOECs used for high-temperature steam electrolysis were found to passivate significantly within a few days when operated at temperatures of $850-950^{\circ} \mathrm{C}$, current densities from -0.5 to $-1 \mathrm{~A} / \mathrm{cm}^{2}$, and partial pressures of steam from 0.3 to $0.9 \mathrm{~atm}$. At low cell polarization (test $\mathrm{A}, 950^{\circ} \mathrm{C}, 90 \% \mathrm{H}_{2} \mathrm{O}$ and $-0.5 \mathrm{~A} / \mathrm{cm}^{2}$ ) only the polarization resistance increased. At high cell polarizations/voltages both the polarization resistance and the ohmic resistance increased.

A substantial amount of $\mathrm{SiO}_{2}$ was detected in the $\mathrm{Ni} / \mathrm{YSZ}$ electrode/electrolyte interface of the tested cells using EDS mapping, whereas no Si was detected in two reference cells. For the test at the lowest cell voltage (test A) the impurities have segregated to the $3 \mathrm{~PB}$ and are found by SEM/EDS as grains of impurities with diameters up to $\sim 1 \mu \mathrm{m}$. For this test the innermost $2 \mu \mathrm{m}$ of the electrode closest to the electrolyte contain the most silica, and the Si-containing impurities are only detected within the innermost $\sim 8 \mu \mathrm{m}$ of this electrode. Point EDS results indicate that these impurity particles consist of a sodium silicate glass. For the test at the highest cell voltage (test B) the impurities have segregated to the interface between the $\mathrm{Ni}$ and the YSZ particles where thin (40-70 nm) Si-containing rims have formed. Impedance spectra recorded during testing reveal large differences in the passivation history for the two electrolysis cells. The dissimilarities in the microstructure and amount of detected Si-containing impurities in the hydrogen electrode of the two tested cells are most likely related to the variation in the electrolysis operation conditions.

\section{Acknowledgment}

Thanks to senior scientist Karin Vels Hansen (Fuel Cell and Solid State Chemistry Department, Ris $\emptyset$ National Laboratory) for providing GDMS data for the raw materials. This work was supported by the EU via project $\mathrm{Hi2H} 2$, contract no. FP6-503765.
Ris $\phi$ National Laboratory assisted in meeting the publication costs of this article.

\section{References}

1. M. Ni, M. K. H. Leung, and D. Y. C. Leung, Chem. Eng. Technol., 29, 636 (2006). 2. V. Utgikar and T. Thiesen, Int. J. Hydrogen Energy, 31, 939 (2006).

3. N. Osada, H. Uchida, and M. Watanabe, J. Electrochem. Soc., 153, A816 (2006).

4. B. Yidiz and M. S. Kazimi, Int. J. Hydrogen Energy, 31, 77 (2006).

5. H. S. Hong, U. S. Chae, S. T. Choo, and K. S. Lee, J. Power Sources, 149, 84 (2005).

6. H. S. Hong, U. S. Chae, K. M. Park, and S. T. Choo, Eco-Materials Processing \& Design Vi, 486-487, 662 (2005).

7. R. Hino, K. Haga, H. Aita, and K. Sekita, Nucl. Eng. Des., 233, 363 (2004).

8. N. Snow, Oil \& Gas J., 104, 26 (2006).

9. P. Dittrick, Oil \& Gas J., 104, 31 (2006).

10. S. Jacobsson and A. Johnson, Energy Policy, 28, 625 (2000).

11. I. Dincer, Renewable Sustainable Energy Rev., 4, 157 (2000).

12. A. Sayigh, Appl. Energy, 64, 15 (1999).

13. S. M. Haile, Acta Mater, 51, 5981 (2003)

14. R. M. Ormerod, Chem. Soc. Rev., 32, 17 (2003).

15. J. M. Ralph, A. C. Schoeler, and M. Krumpelt, J. Mater. Sci., 36, 1161 (2001).

16. S. C. Singhal, Solid State Ionics, 135, 305 (2000).

17. A. O. Isenberg, Solid State Ionics, 3-4, 431 (1981).

18. S. H. Jensen, J. V. T. Høgh, R. Barfod, and M. Mogensen, in Proceedings of The Ris $\phi$ International Energy Conference, L. Sønderberg Petersen and H. Larsen, Editors, p. 204, Ris $\emptyset$ National Laboratory, Denmark (2003).

19. S. H. Jensen, P. H. Larsen, and M. Mogensen, Int. J. Hydrogen Energy, In press 20. G. A. Mills, Fuel, 73, 1243 (1994).

21. Y. L. Liu, S. Primdahl, and M. Mogensen, Solid State Ionics, 161, 1 (2003)

22. K. V. Hansen, K. Norrman, and M. Mogensen, J. Electrochem. Soc., 151, A1436 (2004).

23. K. K. Hansen, P. H. Larsen, Y. L. Liu, B. Kindl, and M. Mogensen, in The 5th European Solid Oxide Fuel Cell Forum, Lucerne, J. Huijsmans, Editor, European Fuel Cell Forum, p. 875 (2002)

24. N. Christiansen, S. Kristensen, H. Holm-Larsen, P. H. Larsen, M. Mogensen, P. V. Hendriksen, and S. Linderoth, in The 5th European Solid Oxide Fuel Cell Forum, Lucerne, J. Huijsmans, Editor, European Fuel Cell Forum, p. 34 (2002).

25. A. Hauch, S. H. Jensen, M. Mogensen, and S. Ramousse, J. Electrochem. Soc., 153, A1741 (2006)

26. N. Bonanos, in Impedance Spectroscopy Theory, Experiment, and Applications, 2nd ed., p. 230, E. Barsoukov and J. R. Macdonald, Editors, Wiley-Interscience, Hoboken, NJ (2005)

27. S. H. Jensen, A. Hauch, P. V. Hendriksen, and M. Mogensen, J. Electrochem. Soc., Submitted.

28. A. Hagen, R. Barfod, P. V. Hendriksen, Y.-L. Liu, and S. Ramousse, Solid Oxide Fuel Cells IX, S. C. Singhal and J. Mizusaki, Editors, PV 2005-07, p. 503, The Electrochemical Society Proceedings Series, Pennington, NJ (2005).

29. Y.-L. Liu, K. Thydén, Q. Xing, and E. Johnson, in Solid State Electrochemistry, Proceedings of the 26th Risoe International Symposium on Materials Science, S. Linderoth, A. Smith, N. Bonanos, A. Hagen, L. Mikkelsen, K. Kammer, D. Lybye, P. V. Hendriksen, F. W. Poulsen, M. Mogensen, and W. G. Wang, Editors, p. 273, Risoe National Laboratory, Roskilde, Denmark (2005).

30. Y. L. Liu and C. G. Jiao, Solid State Ionics, 176, 435 (2005)

31. J. C. Anderson, K. D. Leaver, R. D. Rawlings, and J. M. Alexander, Materials Science, Chapmann \& Hall, New York (1990).

32. R. H. Doremus, Glass Science, John Wiley \& Sons, New York (1973).

33. L. Holland, The Properties of Glass Surface, Chapman and Hall, London (1964)

34. E. P. Butler and J. Drennan, J. Am. Ceram. Soc., 65, 474 (1982).

35. J. M. Jewell, M. S. Spess, and J. E. Shelby, J. Am. Ceram. Soc., 73, 132 (1990).

36. J. M. Jewell and J. E. Shelby, J. Cryst. Growth, 73, 1446 (1990).

37. J. E. Shelby and G. L. Mcvay, J. Non-Cryst. Solids, 20, 439 (1976).

38. A. E. Hughes and S. P. S. Badwal, Solid State Ionics, 46, 265 (1991).

39. N. Jacobson, D. Myers, E. Opila, and E. Copland, J. Phys. Chem. Solids, 66, 471 (2005).

40. N. S. Jacobson, E. J. Opila, D. L. Myers, and E. H. Copland, J. Chem. Thermodyn., 37, 1130 (2005).

41. S. Primdahl and M. Mogensen, J. Electrochem. Soc., 146, 2827 (1999).

42. R. C. Ried, J. M. Prausnitz, and B. E. Poling, The Properties of Gases and Liquids, McGraw-Hill Book Company, New York (1987).

43. N. Q. Minh and T. Takahashi, Science and Technology of Ceramic Fuel Cells, Elsevier Science B.V., Amsterdam (1995).

44. R. Barfod, A. Hagen, S. Ramousse, P. V. Hendriksen, and M. Mogensen, 6th European Solid Oxide Fuel Cell Forum, Lucerne, M. Mogensen, Editor, European Fuel Cell Forum, p. 960 (2004) 